\title{
Sciendo
}

\section{Assessment of the Financial Condition of Knowledge Based Economy Entities - an Example of Polish Video Game Sector}

\author{
Rafat Rydzewski \\ University of Economics in Katowice \\ 1 Maja 50 Street \\ 40-287 Katowice, Poland \\ email: rafal.rydzewski@ue.katowice.pl
}

\begin{abstract}
:
The video game producers are currently in spotlight of market information services. Successes and huge budgets of such companies attract many readers. However, scientific studies related to this sector do not share the same popularity. A reflection on the source of value in this sector shows that what generates revenues is not disclosed in the report. Great examples are customers' relationships or the value of employees creating the game code and story of the game. Video games producers sector presents a good combination of business and culture that allows reflection on financial characteristics of knowledge based companies. Prior studies show that market's valuation takes into account unrecognised assets but capital-intensive character of a production and intangibility of a product and its assets causes problems with exact valuation. In this paper the author asks about the impact of the characteristics on the assessment of a financial condition. The research question in this paper is whether it is possible to use and interpret correctly popular discriminant analysis model for knowledge based entities on the example of video game companies. Results are applicable by analysts and managers of this sector and help to determine the usefulness of this method, but it still depends on assumptions and accounting policies. The reflection presented also broadens the discussion on financialisation because analysed companies can oppose this trend in a specific way.

Keywords: financial condition, financial stability, MDA, discriminant analysis.
\end{abstract}

\section{Introduction}

Day to day activities of managers of companies are to support the financial condition of controlled entity by operational decisions. Most of the activities are reflected by the data presented in financial reports. The data works as a basis for financial analysis done by all stakeholders who want to assess whether the overall situation of a company is good or bad. To meet this quest, various tools are commonly used, among which the financial ratios play a significant role. Financial condition refers to main characteristics of a company such as profitability, liquidity, efficiency, debt levels or risk level. It is related also to a competitive position or creditworthiness of the company which should 
be taken for granted because these main characteristic directly influence the company's position in these areas. All characteristics of the company's situation are always a result of past activities of the company [17]. Despite the numbers of tools used to describe the enterprises "financial condition is a complex phenomenon which means that it is difficult to measure or assess on the basis of one measurable feature" [7, p. 80]. In a large number of possibilities and combinations of different levels of ratios and measures there is a need to clearly define the situation. This need is shed by, for example, discriminatory models where Edward I. Altman is a forerunner with his Z-score model. It is simply a sum of indicator values in appropriate proportions which is understandable for analysts to predict distress of the company. His model has become a standard approach and is widely used by lenders, investors, auditors, bankruptcy lawyers and restructuring advisers. It also shows a way to estimation of other models for company financial condition measurement [1, p. 70]. Still it is based on a result of accounting principles and financial data which, in most cases, does not properly describe the situation of knowledge based entities.

In the author's opinion, among all knowledge based sectors a researcher's attention is mostly attracted by phenomenon of creative industry, which through its diversity and uniqueness shows what was once impossible - it combines different worlds of business and art. One of a greater examples of this misalliance is a video games sector which currently is in spotlight of market information services. Successes, huge production and marketing budgets attract many readers. However, scientific research related to this sector does not share the same popularity. Of course, the sector and every business can be only a setting for analysed problem in the scientific study, however, the features of it serve a multitude of references to current topics. Most of them are a result of intangible character of its value sources which has no full refection in the financial report. Good examples are customer relationships or the value of employees creating the game code and story of the game. These all are a part of intellectual capital (IC) which gives the companies competitive advantage [5]. Despite trends to include more data about IC there is no consensus on the methods [15]. As a financial statement does not include all assets, true view on the profitability is impossible and can reach abnormal levels. Because accounting problems with activating the production costs on the liquidity of the companies of video games sector becomes incomparable [19]. Prior author's studies show also that the video games sector represents higher level of price to book ratio. This proves that these unrecognised assets are taken into account in valuation by stock market investors [20]. This situation leads to a reflection on the methods of assessing the financial situation of the company.

The research question in this paper is whether it is possible to use and interpret correctly popular discriminant analysis model for knowledge based entities on the example of video game companies. Answering this question will allow a better understanding of the situation of entities of this sector and, by comparison, can be applied to other knowledge based economy entities. According to the early stage of research a formulation of hypotheses is abandoned. Because of its simplicity, the Polish video game sector has been chosen for the analysis. This sector is in an early stage of development and most of its entities are not engaged in other sectors. So result of these companies is directly related to its intangible source of value. The popularity of this sector among investors on the Polish capital market will also allow for the analysis of the discussed phenomenon in relation to the capital market, which will greatly facilitate answering the research question.

\section{Financial Condition}

Assessing financial condition of the company lays in a ground of a vast number of scientific papers and other studies. ${ }^{1}$ Multiple discriminant analysis (MDA) is just one of many methods that an analysts can use. It makes it possible to predict the financial condition of economic entities. The result obtained in the calculated and presented models usually allows to determine whether a given entity is characterized by financial problems. These models are often used to assess the risk of bankruptcy [16, p. 251]. However, the result itself is only an assessment and is not a method of counteracting possible crises. The most popular example of discriminant analysis today is the first 
model of this type used to analyse a threat of bankruptcy developed by E. I. Altman in 1968. It included five popular financial ratios, which in the form of a linear function allowed to distinguish entities in a distress situation from those which are not [16, p. 251]. For the 50th anniversary of its first publication the author published a work where he discussed a number of applications and possible extensions. He also concluded that despite the fact that some researchers have developed more advanced methods of predicting risk of default Z-score remains still popular due to its simplicity [1, p. 70], [2, pp. 1-2]. In 2017 Altman et al. tested the model and showed that it performed well on the international scale [3].

As the Polish video game sector has been chosen as an example for this study, the author has reviewed a current state of research in this field according to this market and its economic condition. A worth-mentioning work, is the one on MDA of Visegrad group countries in which authors develop their own models for enterprises of this region. They also show that the most significant predictors of bankruptcy are the levels of: current assets to current liabilities ratio, net income to total assets ratio, ratio of non-current liabilities and current liabilities to total assets, cash and cash equivalents to total assets ratio and return of equity [14]. All of them are a part of developed models.

Artur Paździor and Maria Paździor have analysed WIG-INFO ${ }^{2}$ index companies, to which a two big video game companies belonged in the past. Their work was to "identify determinants of changes in market prices of shares of companies" [18, p. 156] included in this index which makes these considerations very similar to this study. The main part of their work is a correlation coefficient analysis in which they found out that rate of return of the companies is mostly related to: total debt ratio, index of the golden balance rule (equity/non-current assets), profit margin on sales, return on equity. Authors of the work also refer to the situation in which market price exceeds its book value and "goes beyond the traditional accounting framework" and gives examples of brand, distribution network, trade contacts and intellectual potential of employees [18, p. 157]. Assets related to knowledge are also a part of informatics sector and this work can broaden these conclusions. Relation of MDA models related to sector specific are a common topic of some

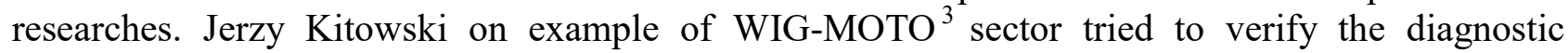
reliability of discriminatory models [13]. He drew attention to the fact that the authors of the models do not focus on errors related to the selection of a test sample for an assessment of the probability of bankruptcy. Authors show that there are differences in "bankruptcy" criteria. In his analysis Kitowski stressed the fact that not all models take into consideration all categories of ratios, which additionally increases a risk of an incorrect diagnosis as the specificity of the analysed sector should be also take into consideration. Similar attitude is reflected in works of Sofie Balcaen and Hubert Ooghe [4] and Marek Gruszczyński [10]. The main problems are: the linearity assumption, use of annual accounts information, ratios with use of different components, neglecting the multidimensional nature of failure, methodological shortcomings, no reference to other methods present in the literature. However work of Edward I. Altman, Małgorzata Iwanicz-Drozdowska, Erkki K. Laitinen and Arto Suvas, summarized its verification of Z-score models with a statement that an influence of an age of the firm, its industry and country of origin is marginal. Because of that the original model performs well in an international context but "may be somewhat improved with country-specific estimation" [3, p. 167].

According to the setting of this work video games sector appears in works dedicated to financial condition only by its representatives among other examples. Kinga Olszewska and Tomasz Turek use example of CD Projekt and present only good results of this company with use of MDA as an information instrument used in financial condition of the company [17]. Among some other research the example of touristic sector can be useful. Nature of this sector is related to the prepaid character of service which affects the solvency of travel agents. Grzegorz Gołębiowski and Agnieszka Pląsek have analysed efficiency of discriminant models and concluded that the financial condition of travel agents is best described by: current liquidity, operating profitability, sales profitability, debt coverage ratio [8]. It is worth to refer to this result in case of video game sector in which the opposite situation takes place. Such companies spend relatively huge amount of money first, in order to get the results after introducing their product. 
Another thread in MDA research is an assessment of their effectiveness. The results show that in more than $80 \%$ of cases financial problems could have been identified two years before bankruptcy [9]. However, despite such results, the quality of Polish bankruptcy models and the appropriateness of variable selection are rarely raised, as mentioned above [10]. Further research directions are focused on modifications and extensions, new variables and still testing models in different countries [3].

\section{Methodology}

Having reviewed the literature in search for some appropriate tools to answer the research question about the possibility of using discriminatory models to assess financial situation of the video game sector, there are some steps to be followed:

- distinguish and group financial ratios used to describe financial condition on the basis of selected discrimination models and literature review,

- analyse a possible impact of sector specificity on the level of these ratios,

- analyse the correlation of changes in these ratios with changes in the market price of shares of selected companies in the video game sector in the first days after publication of financial data noticeable correlations will confirm the information value of a given indicator, making the models using them more valuable in assessment, ${ }^{4}$

- analysis of the results of selected MDA models - regardless of the results of the correlation analysis, a review of the values obtained from the selected models may allow to draw conclusions on the usefulness of this models.

\section{Research sample}

The 12 largest listed companies in the sector have been chosen to analyse the results of selected MDA models. The choice was done according to the Forbes report 'The largest Polish game producers. Polish gaming industry in 2018' for which financial data from quarterly reports for the last 3 years is available (data from Q4 2016; Techland, which is not a public company, and One More Level, which operated in another sector during the analysis, have been omitted). The data used for the analysis was obtained from the NOTORIA services (financial statements data) and stooq.pl website (stock market data).

\section{MDA models chosen for a selection of ratios}

On a basis of literature review the subjective choice of MDA has been done. The summary of selected models with its interpretation is presented in the table below.

Table 1. Summary of discriminatory distress prediction models.

\begin{tabular}{|c|c|c|}
\hline $\begin{array}{c}\mathscr{\infty} \\
\stackrel{0}{0}\end{array}$ & \multicolumn{2}{|c|}{$\begin{array}{c}\text { Z-Score }=1,2 X_{1}+1,4 X_{2}+3,3 X_{3}+0,6 X_{4}+1.0 X_{5} \\
\text { EM-Score }=6,56 X_{1}+3,26 X_{2}+6,72 X_{3}+1,05 X_{4}+3,25\end{array}$} \\
\hline 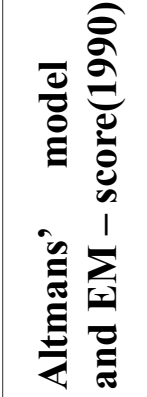 & $\begin{array}{l}\text { where: } \\
\text { X1 - Working capital/Total assets } \\
\text { X2 - Retained earnings/Total assets } \\
\text { X3 - Earnings before interest \& taxes/Total } \\
\text { assets } \\
\text { X4 - Market value of equity/Book value of } \\
\text { total liabilities } \\
\text { X5 - Sales/Total assets }\end{array}$ & $\begin{array}{l}\text { Results higher than } 5.85 \text { correspond to a } \\
\text { rating from BBB to AAA and results } \\
\text { below } 4.5 \text { indicate significant financial } \\
\text { problems. }\end{array}$ \\
\hline $\mathscr{I}$ & \multicolumn{2}{|c|}{$Z_{M}=1,5 X_{1}+0,08 X_{2}+10 X_{3}+5 X_{4}+0,3 X_{5}+0,1 X_{6}$} \\
\hline
\end{tabular}




\begin{tabular}{|c|c|c|}
\hline & $\begin{array}{l}\text { where: } \\
\text { X1 - (gross profit }+ \text { amortization) /total } \\
\text { liabilities; } \\
\text { X2 - total assets / total liabilities; } \\
\text { X3 - gross profit /total assets; } \\
\text { X4 - net profit / revenues; } \\
\text { X5 - inventories/ revenues } \\
\text { X6 - revenues /total assets }\end{array}$ & $\begin{array}{l}\mathrm{Z}_{\mathrm{M}}<0 \text { enterprise threatened with } \\
\text { bankruptcy } \\
\mathrm{O}<\mathrm{Z}_{\mathrm{M}}<1 \text { company with a poor result, but } \\
\text { not in danger of bankruptcy } \\
1<\mathrm{Z}_{\mathrm{M}}<2 \text { company in good financial } \\
\text { condition } \\
\mathrm{Z}_{\mathrm{M}}>2 \text { company is in very good financial } \\
\text { condition }\end{array}$ \\
\hline & \multicolumn{2}{|c|}{$F D=3,562 X_{1}+1,588 X_{2}+4,288 X_{3}+6,719 X_{4}-2,368$} \\
\hline 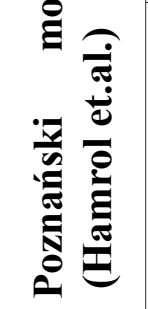 & $\begin{array}{l}\text { where: } \\
\text { X1 - net profit /total assets; } \\
\text { X2 - (current assets - inventories) / current } \\
\text { liabilities; } \\
\text { X3 - fixed capital /total assets; } \\
\text { X4 - profit on sales / revenues from sales }\end{array}$ & $\begin{array}{l}\mathrm{FD}<0 \text { bad financial situation } \\
\mathrm{FD}>0 \text { good financial situation }\end{array}$ \\
\hline & \multicolumn{2}{|c|}{$\begin{aligned} Z_{H A}= & 2,36261+0,365425 X_{1}-0,765526 X_{2}-2,40435 X_{3} \\
& +1,59079 X_{4}+0,00230258 X_{5}-0,0127826 X_{6}\end{aligned}$} \\
\hline 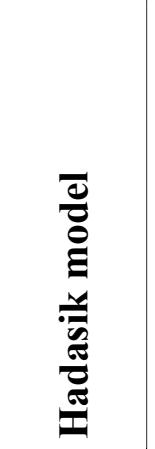 & $\begin{array}{l}\text { where: } \\
\text { X1 - current assets/current liabilities } \\
\text { X2 - (current assets - inventories) / current } \\
\text { liabilities } \\
\text { X3 - total liabilities / total assets } \\
\text { X4 - (current assets }- \text { short-term liabilities)/ } \\
\text { total assets } \\
\text { X5 - receivables / revenues } \\
\text { X6 - inventories / profit on sales }\end{array}$ & $\begin{array}{l}\mathrm{ZHA}<0 \text { bad financial situation } \\
\mathrm{ZHA}>0 \text { good financial situation }\end{array}$ \\
\hline 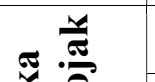 & \multicolumn{2}{|c|}{$Z_{P S}=0,644741 X_{1}+0,912304 X_{2}$} \\
\hline 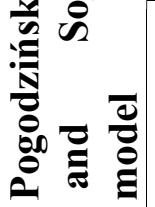 & $\begin{array}{l}\text { where: } \\
\text { X1 - (current assets - inventories) / current } \\
\text { liabilities } \\
\text { X2 - gross profit / revenues }\end{array}$ & $\begin{array}{l}\text { ZPS }<0 \text { bad financial situation } \\
Z \mathrm{PS}>0 \text { good financial situation. } \\
\text { "grey zone" from }-0,454 \text { to } 0,09\end{array}$ \\
\hline
\end{tabular}

Source: own work on a basis of [6 p.147, 11, 21 pp.222].

\section{Results}

The first step of analysis was a selection and group of ratios used for assessing the financial condition. Table 2 presents all ratios in four groups covering main characteristics of the companies. The first group - profitability - presents the biggest number of ratios. It suggests that profitability is the most important part of a financial situation. On asset side of a balance sheet there is no information about the knowledge possessed by the company as well as reliable information on value of the production in progress. As not all assets are presented in the financial statement the profitability assessment in this aspect is out of reach. All nominators of the ratios in this sector are exposed to high variability depending on the video game production stage. Production process takes a few years and sales begins with the release of the game. In an early production stage the company may record low levels of these ratios, which cannot correspond to its true situation. Nevertheless, before any profits from sales occur, the company has to manage its costs wisely to reach the premiere day. This leads us to the liquidity where sectors characteristic is over-liquidity. To secure a long-term production process, companies accumulate large amounts of liquid financial resources. The situation is also hampered by differences in the recognition of expenditure on video games 
influencing the structure of assets. Some companies classify this expenditure as inventories, some as intangible assets, which prevents comparability of liquidity ratios between companies [19]. For that reason a further analysis of other ratios based on levels of inventories was abandoned. The leverage ratios also depend on the sector characteristic where the significant part of passive side is taken by equity. High risk of production and uncertainty of results increases cost of external financing and influences the capital structure where a main role is given to equity. Summarizing, the sector's characteristics affect all of the areas analysed in this paper. Because of that, analysis of financial condition can be incompetent to decide about the company of this sector.

Table 2. Summary of variables employed in MDA models.

\begin{tabular}{|c|c|}
\hline Profitability & Liquidity \\
\hline $\begin{array}{ll}\text { 1. } & \text { EBIT / total assets } \\
\text { 2. } & \text { gross profit / revenues } \\
\text { 3. } & \text { gross profit / total assets; } \\
\text { 4. net profit / equity } \\
\text { 5. net profit / revenues; } \\
\text { 6. net profit / total assets; } \\
\text { 7. } \text { profit on sales / revenues } \\
\text { 8. } & \text { revenues / total assets }\end{array}$ & $\begin{array}{l}\text { 1. (current assets - current liabilities) } \\
\text { / total assets } \\
\text { 2. (current assets - inventories) } \\
\text { / current liabilities } \\
\text { 3. cash and cash equivalents / total assets } \\
\text { 4. current assets / current liabilities } \\
\text { 5. current assets / total assets } \\
\text { 6. (gross profit + amortization) } \\
\text { / total liabilities; }\end{array}$ \\
\hline Leverage / Debt & Others \\
\hline $\begin{array}{l}\text { 1. fixed capital / total assets; } \\
\text { 2. retained earnings / total assets } \\
\text { 3. total assets / total liabilities; } \\
\text { 4. total liabilities / total assets } \\
\text { 5. equity/ non-current assets }\end{array}$ & $\begin{array}{l}\text { 1. market value of } \\
\text { /book value of total liabilities } \\
\text { 2. receivables / revenues } \\
\text { 3. inventories / profit on sales } \\
\text { 4. inventories / revenues }\end{array}$ \\
\hline
\end{tabular}

Source: own work.

Second part of this work constitutes an analysis of the correlation between the selected ratios and changes of market valuations of these companies. If these ratios are meaningful for description of financial condition in the first days after release new financial data should be reflected by changes in market valuation of the company. Results presented in the Table 3 do not show a correlation between changes of analysed ratios and market valuation. A review of results for single companies often gives different correlations coefficients. For some of them relations of market valuation and profitability was positive (more than 0,7 ) and the same ratios for another company was negative (less than -0,4). Drawing conclusions based on that data is complicated. The video game sector has various relations so it could be stated that these ratios are not a basis for investment decisions of market participates or these changes were already in price before the release date.

Table 3. Correlation coefficient of changes of analysed ratios and changes of market valuation.

\begin{tabular}{|l|l|l|l|l|l|l|}
\hline Ratios & +1 day & +2 days & +3 days & +4 days & +5 days \\
\hline Profitability & 0,08 & 0,10 & 0,10 & 0,10 & 0,11 \\
\hline EBIT / total assets & 0,00 & $-0,02$ & 0,00 & $-0,01$ & 0,03 \\
\hline gross profit / sales & 0,00 & 0,00 & 0,03 & $-0,02$ & 0,01 \\
\hline gross profit / total assets; & 0,05 & 0,12 & 0,12 & 0,06 & 0,07 \\
\hline net profit / equity & $-0,04$ & $-0,05$ & $-0,04$ & $-0,03$ & $-0,03$ \\
\hline net profit / revenues; & $-0,04$ & $-0,03$ & $-0,03$ & $-0,03$ & $-0,04$ \\
\hline net profit / total assets; & & & & & \\
\hline
\end{tabular}




\begin{tabular}{|c|c|c|c|c|c|}
\hline profit on sales / revenues & $-0,02$ & 0,05 & 0,03 & $-0,01$ & 0,00 \\
\hline revenues / total assets & 0,09 & $-0,15$ & $-0,17$ & 0,06 & 0,06 \\
\hline \multicolumn{6}{|l|}{ Liquidity } \\
\hline $\begin{array}{l}\text { (current assets - current liabilities)/ total } \\
\text { assets }\end{array}$ & 0,36 & 0,00 & 0,01 & 0,12 & 0,11 \\
\hline $\begin{array}{l}\text { (current assets }- \text { inventories) / current } \\
\text { liabilities }\end{array}$ & 0,09 & 0,12 & 0,09 & 0,04 & 0,00 \\
\hline cash and cash equivalents / total assets & 0,07 & $-0,10$ & $-0,11$ & 0,06 & 0,05 \\
\hline current assets / current liabilities & 0,11 & 0,10 & 0,06 & 0,05 & 0,00 \\
\hline current assets / total assets & 0,05 & 0,05 & 0,03 & 0,00 & $-0,05$ \\
\hline (gross profit + amortization) / total liabilities; & 0,16 & 0,12 & 0,14 & 0,09 & 0,05 \\
\hline \multicolumn{6}{|l|}{ Leverage / Debt } \\
\hline fixed capital/ total assets; & 0,13 & 0,07 & 0,06 & 0,05 & 0,00 \\
\hline retained earnings/total assets & 0,03 & 0,02 & 0,02 & $-0,09$ & $-0,07$ \\
\hline total assets /total liabilities; & 0,09 & 0,11 & 0,06 & 0,05 & 0,05 \\
\hline equity/ non-current assets & 0,01 & 0,08 & 0,06 & $-0,07$ & $-0,05$ \\
\hline \multicolumn{6}{|l|}{\begin{tabular}{|l|} 
Others \\
\end{tabular}} \\
\hline receivables / revenues & $-0,05$ & $-0,05$ & $-0,02$ & $-0,14$ & $-0,11$ \\
\hline
\end{tabular}

Source: own work based on NOTORIA and stooq.pl services data.

The analysis presented above is based on the efficiency of the market. As some information may be priced before the exact release of financial data, some longer periods have to be taken into consideration. Low levels of correlation coefficients should not be a strong basis of inference about the usefulness indicators used in the models. Table 4 presents a simple ranking of companies based on the three selected models. All of the models were positioned (1-lowest score, 12- the highest score) and their sum was calculated making a ranking. This ranking was also compared to a change in the stock exchange rate of companies over a period of four quarters until the end of June and the end of September 2019. This analysis of the results enables to put companies in order taking into account both the financial condition and the volatility of the market price of shares. It can be stated that models give useful information except companies such as:

- 11BIT, which recorded low and negative rates of return on shares despite relatively high levels of analysed models;

- ARTIFEX obtained the lowest result in the Mączyńska model, which suggests that in the two other models some ratios significant for this sector were omitted. The variability of the value of shares indicates the loss of half of the market capitalization in the analysed period;

- CI Games, which despite poor results describing its financial condition, obtained a stable result of changes in share prices on the market. 
Table 4. Ranking of results obtained from selected discriminatory models for the analysed Polish video game sector companies.

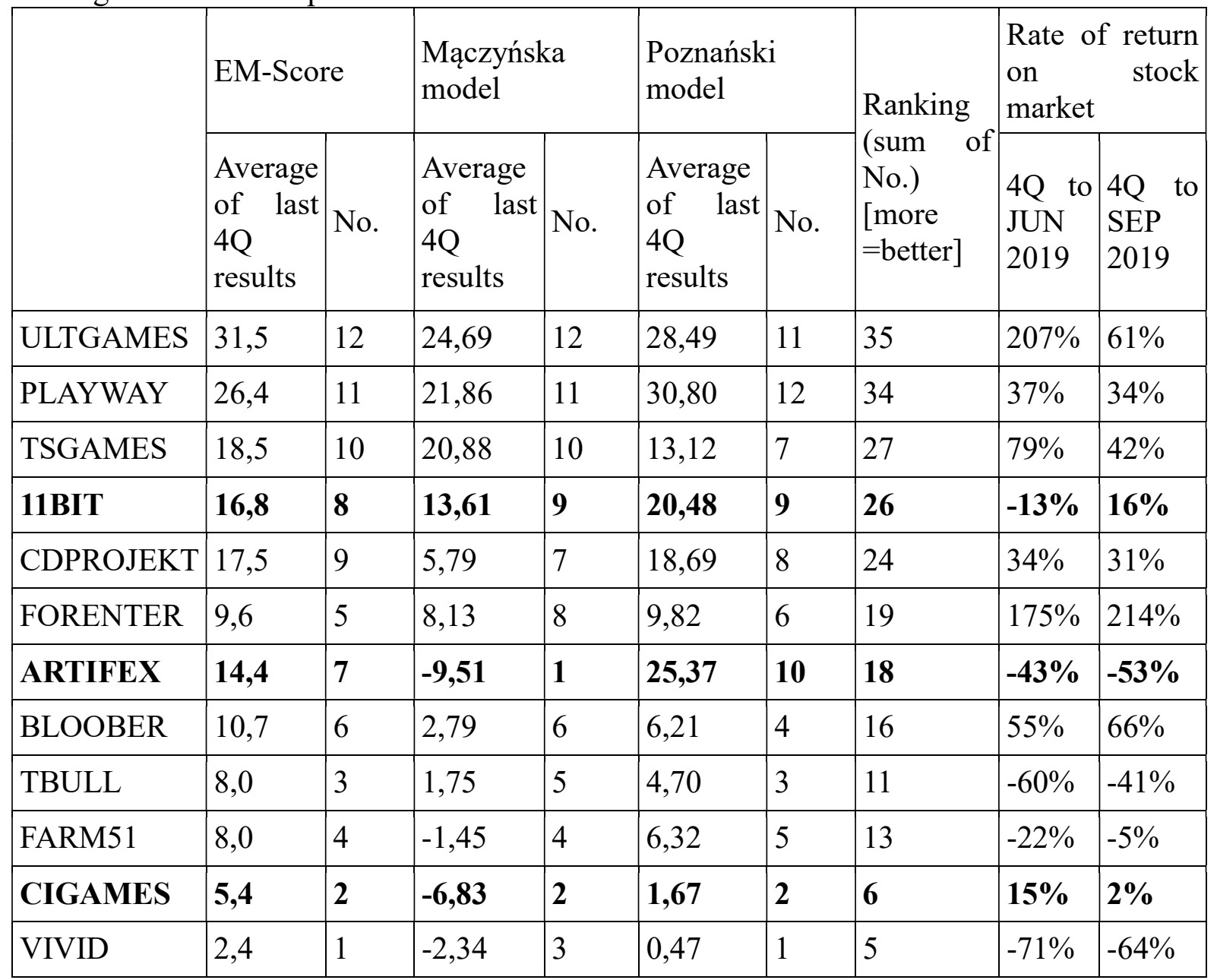

Source: own work on a basis of NOTORIA and stooq.pl services.

These results of the analysis indicate a relatively satisfactory level of assessment, especially aimed at comparing the condition of various entities. Up to this point, the analyses were done to assess the situation of the companies. Only one of the companies listed in this sector has declared bankruptcy so far. This is Nicolas Games SA, bankruptcy history of which is centred between two dates. The first is February 2012, when the Nawar Company filed for bankruptcy. The second is June 2015, when the company's management board filed for bankruptcy. Figure 1 shows the variability of MDA models for this company clearly indicates that in 2013-2015 the situation was assessed as good by all three models. 
Figure 1. Variability of results of selected discriminatory models for NICOLAS GAMES SA in the period from Q2 2008 to Q1 2015.

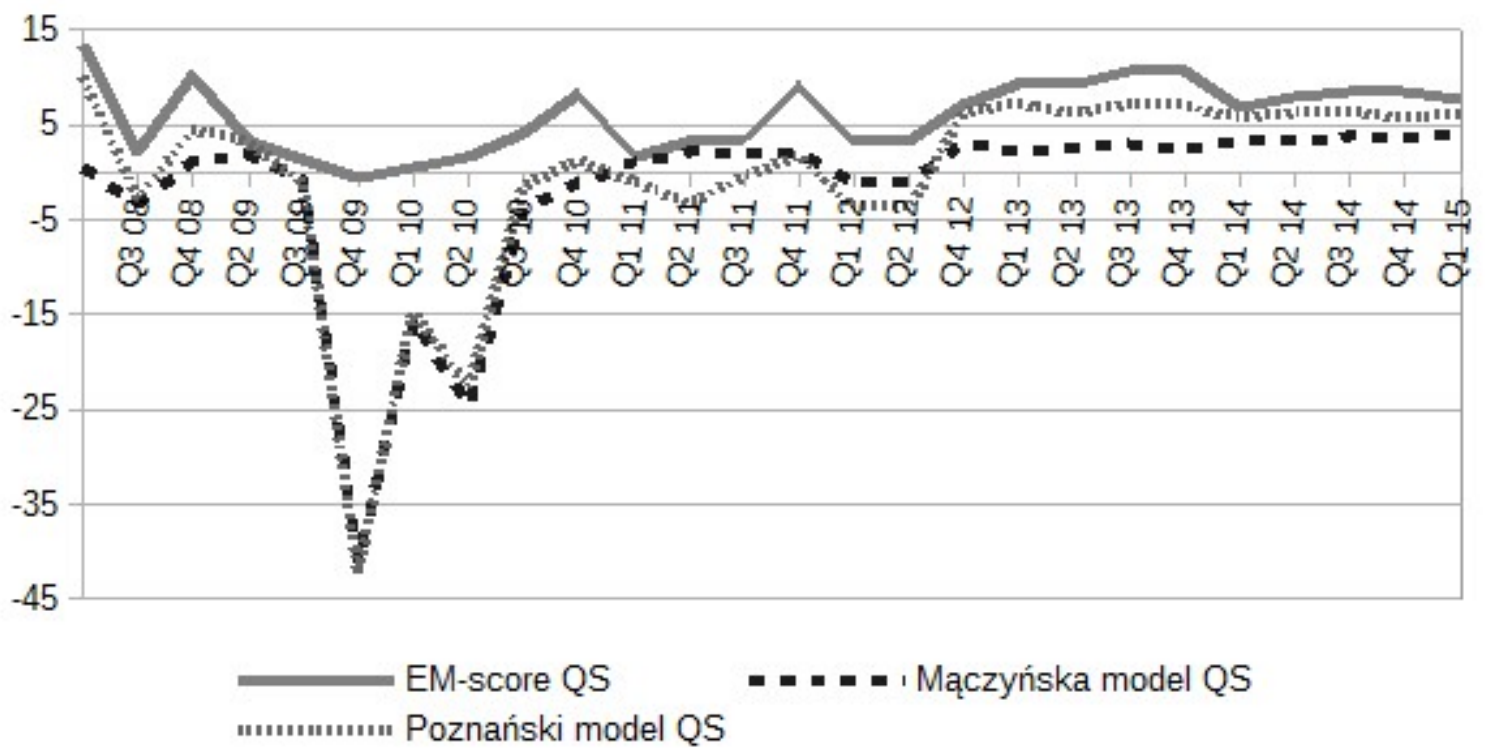

Source: own work on a basis of NOTORIA.

\section{Conclusions}

Discriminatory models are described in literature as not very widespread, but efficient and attractive analytical tools [16, p. 249] which, with relatively high reliability, they constitute the "basis for analysing the economic and financial condition of enterprises" [11, p. 21]. The research question in this paper was whether it is possible to use and correctly interpret popular discriminant analysis model for knowledge based entities on the example of video game companies. The answer to this question is not clear. Relations of main ratios used in MDA models shows that these indicators may prove worthless for analysis of this sector because of its characteristics. Also a correlation coefficients analysis of these ratios with market valuation does not show any significant relations. However, the ranking of results of selected models ordered companies relatively well with reference to long term market valuation trends.

In the analysed works a limited impact of financial and economic situation on the market price can be observed. This is caused by popularity of technical analysis [18] and some other factors including undisclosed assets and other information. Investors take into account other factors as shown in the market to book ratio analysis as well [20]. Also, Paździor and Paździor in their works suggest that financial situation of companies has a rather limited impact on the market price of their shares [18, p. 157]. This study shows some limitations mainly in assumption that investors make decisions based on an analysis of financial results. The second limitation is the lack of companies that have declared bankruptcy, so the model analysis focused only on ranking the results and not on the assess the risk of bankruptcy. The third limitation is imperfection of the research subject related to the imperfection of accounting policy. This translates into a large part of the problems with assessing profitability and liquidity. It remains to be determined whether this situation is more a limitation and whether the assumption to be made.

The inability to assess the entity's situation based on financial indicators, which is the case of video game companies, is an interesting phenomenon in the context of financialisation. The sector belonging to the most popular among stock market investors is not fully described by the tools available for a financial analyst. Further research in this field should consider the preparation of model on a basis of a subjective selection of companies in bad and good financial condition. Nevertheless, the in-depth research into the sources of financial condition in companies in this sector and other creative industries will significantly broaden the knowledge about the assessment of knowledge based companies. 


\section{References}

1. Altman, E. I. Applications of distress prediction models: What have we learned after 50 years from the Z-Score models? International Journal of Financial Studies 6 (3), 2018, pp. 1-15.

2. Altman, E. I., E. Hotchkiss, and W. Wang. Corporate financial distress, restructuring, and bankruptcy: analyze leveraged finance, distressed debt, and bankruptcy, John Wiley \& Sons, Hoboken, New Jersey, 2019.

3. Altman, E. I., M. Iwanicz-Drozdowska, E. K. Laitinen, and A. Suvas. Financial distress prediction in an international context: A review and empirical analysis of Altman's Z-score model, Journal of International Financial Management \& Accounting 28 (2), 2017, pp. 131-171.

4. Balcaen, S., and H. Ooghe. 35 years of studies on business failure: an overview of the classic statistical methodologies and their related problems, The British Accounting Review 38 (1), 2006, pp. 63-93.

5. Billiot, M. J., and S. Glandon. The Impact of Undisclosed Intangible Assets on Firm Value, Journal of Accounting \& Finance Research 13 (2), 2005, pp. 67-78

6. Bombiak, E. Modele dyskryminacyjne jako metoda oceny sytuacji finansowej przedsiębiorstw, Zeszyty Naukowe Akademii Podlaskiej. Seria: Administracja i Zarzadzanie, 13 (86), 2010, pp. 141 152

7. Dziekański, P. Spatial Differentiation of the Financial Condition of the Świętokrzyskie Voivodship Counties, Barometr Regionalny 14 (3), 2016, pp. 79-91.

8. Gołębiowski, G., and A. Pląsek. Skuteczność wybranych modeli dyskryminacyjnych na przykładzie branży turystycznej, Studia i Prace Kolegium Zarządzania i Finansów 164, 2018, pp. 9-24.

9. Gołębiowski, G., and K. Żywno. Weryfikacja skuteczności modeli dyskryminacyjnych na przykładzie wybranych spółek giełdowych, Współczesna Ekonomia 2 (3), 2008, pp. 31-45.

10. Gruszczyński, M. Błędy doboru próby w badaniach bankructw przedsiębiorstw, Kwartalnik Nauk o Przedsiębiorstwie 3, 2017, pp. 22-29.

11. Hamrol, M., and J. Chodakowski. Prognozowanie zagrożenia finansowego przedsiębiorstwa. Wartość predykcyjna polskich modeli analizy dyskryminacyjnej, Badania operacyjne $i$ decyzje 3, 2008, pp. 17-32.

12. Hońdo, T. Model Altmana, czyli lupa, przez którą można wypatrzyć kandydatów na bankrutów, https://www.parkiet.com/Profesjonalny-inwestor/311159816-Model-Altmana-czyli-lupa-przez-

ktora-mozna-wypatrzyc-kandydatow-na-bankrutow.html [access date: 08.04.2020].

13. Kitowski, J. Próba weryfikacji wiarygodności diagnostycznej modeli dyskryminacyjnych (na przykładzie spółek portfela WIG-motoryzacja), Przedsiębiorczość i Zarządzanie 19 (10), cz. 1 Finansowe i organizacyjne aspekty kooperacji nauki i lokalnej przedsiębiorczości-wymiar teoretyczny i praktyczny. Część 1, 2018, pp. 177-191.

14. Kliestik, T., J. Vrbka, and Z. Rowland. Bankruptcy prediction in Visegrad group countries using multiple discriminant analysis, Equilibrium. Quarterly Journal of Economics and Economic Policy 13 (3), 2018, pp. 569-593.

15. Niemczyk, L. Kapitat intelektualny $w$ księgach rachunkowych oraz sprawozdawczości przedsiębiorstwa, Rzeszów: Wydawnictwo Uniwersytetu Rzeszowskiego, 2015.

16. Nowak, E. Analiza sprawozdań finansowych, Warszawa: PWE, 2005.

17. Olszewska, K., and T. Turek. Analiza dyskryminacyjna jako narzędzie informacyjne w zakresie kondycji finansowej przedsiębiorstwa, Zeszyty Naukowe Politechniki Czesstochowskiej. Zarzadzanie 31, 2018, pp. 175-186.

18. Paździor, A., and M. Paździor. Determinants of Changes in Stock Market Prices Based on Companies in the WIG-INFO Index, Zeszyty Naukowe Wyższej Szkoły Bankowej w Poznaniu 79, 2018, pp. 155-163.

19. Rydzewski, R. Problem analizy płynności sektora producentów gier wideo w Polsce, Studia Ekonomiczne 377, 2018, pp. 97-111.

20. Rydzewski, R. Market-to-Book Ratio and Creative Industries--Example of Polish Video Games 
Developers, Economics and Culture 16 (1), 2019, pp. 137-147.

21. Wojnar, J. Ocena skuteczności modeli analizy dyskryminacyjnej do prognozowania zagrożenia finansowego spółek giełdowych, Zeszyty Naukowe Małopolskiej Wyższej Szkoły Ekonomicznej w Tarnowie 1 (24), 2014, pp. 221-231.

WWW 1.

\section{Notes}

1. Quick look at main key words with use of Google Scholar search engine results with following number of publication: 4820000 for "financial analysis", 4540000 for "financial condition", 2 260000 for "financial distress"; 601000 for "z-score"(respectively also for results only from 2015: $1420000 ; 1110000 ; 195000 ; 49$ 300).

2. WIG-INFO (informatics) is a sector index of companies listed on Warsaw Stock Exchange.

3. WIG-MOTO (automotive) is a sector index of companies listed on Warsaw Stock Exchange.

4. This assumption allows to conduct some basic research applying to a wide range of analysed companies. The use of correlation analysis may lead to incorrect results because before the publication of financial report expectations of market participants are already reflected in the price. The necessity to assess investors' expectations before publication would require limiting the number of analysed entities and adding more assumptions related to evaluation of their predictions. 